Forthcoming in The Palgrave Handbook on Toleration. Ed. Mitja Sardoč.

\title{
Toleration and Liberty of Conscience
}

Jon Mahoney

Department of Philosophy

Kansas State University

Email: jmahoney@ksu.edu

\begin{abstract}
This chapter examines some central features to liberal conceptions of toleration and liberty of conscience. The first section briefly examines conceptions of toleration and liberty of conscience in the traditions of Locke, Rawls, and Mill. The second section considers contemporary controversies surrounding toleration and liberty of conscience with a focus on neutrality and equality. The third section examines several challenges, including whether non-religious values should be afforded the same degree of accommodation as religious values, whether liberty of conscience requires a secular state, and how bias impedes understandings of toleration and liberty of conscience. The chapter concludes with brief comments on future directions for research on toleration and liberty of conscience. One is exploring toleration and liberty of conscience in non-Western contexts; another is exploring ways that varieties of religious and political identity impact conceptions of toleration and liberty of conscience.
\end{abstract}

Key Words: toleration; liberty of conscience; the harm principle; equality; neutrality; fairness; liberalism; rights; religious minorities; non-religious conscience; secularism; political authority

Liberty of conscience is central to liberal conceptions of toleration. One tradition that runs from John Locke (1983) through John Rawls (2005) holds that liberty of conscience is a fundamental right. A conception of the person as free and equal is a primary moral basis for toleration on this view. John Stuart Mill (1978) represents another tradition. On his view, utility is the moral basis for toleration and liberty of conscience. Both collective and individual interests are best promoted by a policy of toleration that extends to religious among other value commitments. The limits to liberty are set by the harm principle: toleration extends to beliefs and actions that do not cause or pose a significant risk of harm to others. Political philosophers in both traditions claim that liberty of conscience is a fundamental feature to a liberal conception of toleration. 
Recent proposals on how modern, diverse, and multi-religious states can best honor their commitments to toleration and liberty of conscience are often efforts to adapt ideas from traditional liberal thought to contemporary political and legal contexts. Two influential views are the neutrality and equality approaches to liberty of conscience (Patten, 2017; Nussbaum, 2008). Defenders of neutrality claim that a tolerant state is one whose policies are neutral toward religious values and practices. Others claim that toleration is best realized by a commitment to religious equality, one that treats each religious practice and conviction without favoritism or prejudice. Some argue that since religious values as a class are special, a liberal state can give some preferential treatment to religious exemption claims. Critics of this view reasonably argue that for reasons of fairness a tolerant state will treat religious and non-religious values with equal regard (Leiter, 2012; Perry, 2018).

This chapter proceeds as follows. Part I briefly sets out main ideas in the LockeRawls and Mill traditions on toleration and liberty of conscience. Part II examines contemporary neutrality and equality approaches to toleration and liberty of conscience. Part III considers three challenges. First is the claim that toleration should mean the same thing for religious and non-religious convictions. Second, whether liberal toleration requires a secular state. Third, the legitimate worry that prevailing conceptions of toleration and liberty of conscious are objectionably exclusionary. Part IV concludes with a brief comment on issues for future research and reflection.

\section{Two Models of Toleration and Liberty of Conscience}

In its contemporary form the Locke-Rawls paradigm holds that citizens and government must tolerate the religious convictions of persons whatever their content, unless such 
convictions imperil the rights of others. Although there is common ground within this tradition of liberalism, it is important to highlight some important differences.

Locke famously claimed that atheists, Catholics, and 'Turks' ought not to be tolerated because they cannot be trusted to honor a social contract between citizens to uphold rights to life, liberty, and property (Locke, 1978). On this view, atheists are excluded from the group of persons to be tolerated because, fearing no divine sanctions for breaking their promises, they are unreliable partners to a social contract. If you cannot trust an atheist to keep her or his promise then you cannot trust an atheist to comply with the terms of one of the most important promises of all, the social contract. Catholics on Locke's view are conflicted, as are 'Turks', which is Locke's conflation of Muslims with Muslim citizens of the Ottoman state. The political loyalty of a Catholic or 'Turk' to a liberal state, according to Locke, will be mitigated their loyalty to the Papacy or the Ottoman Sultan.

On a charitable interpretation Locke is committed to something like the following loyalty test: Do they endorse a view at odds with the essential requirements for a social contract between citizens committed to a liberal state? If 'yes', toleration does not extend to them. Citizens can reasonably be expected to endorse a model of political authority whose jurisdictional authority over civil affairs is not compromised by the authority of a religious institution. Yet in actuality Locke formulates the limits of toleration in a way that affirms pre-existing prejudices as well as seriously misinformed beliefs about political and religious authority within Islam.

Locke's conception of political morality also explicitly depends on his conception of Christian morality. Locke states that his Letter Concerning Toleration expresses "my 
thoughts about the mutual toleration of Christians" (Locke, 1978: 23). The political morality that is the basis for his account of political authority, liberty, and equality is a Christian conception of natural law.

Contemporary liberals in the Lockean tradition defend more inclusive conceptions of toleration and seek in general to extend the limits of toleration as far as possible within the boundaries of basic rights. Robert Nozick's (1974) famous construal of negative rights as side-constraints offers a model on how to formulate this idea: there are some things a person can do on the basis of her religious convictions that no one has a right to interfere with. Toleration understood in this way will not be objectionably exclusionary in that way Locke's position was. Yet we'll see in Part III that challenging issues remain for any attempt to defend an inclusive conception of toleration.

After his turn to political liberalism Rawls (2005) sought to present the case for liberal toleration in a way that could unite as many persons who are committed to fair terms for social cooperation as possible. Toleration extends, up to a point, to political philosophy itself. Provided someone is willing to seek fair terms for social cooperation in a state committed to treating each citizen as free and equal, she is to be tolerated. Someone's commitment to a minority or any religion is irrelevant in the sense that anyone willing to abide by the fair terms for social cooperation is entitled to liberty of conscience and the full protections of an inclusive tolerant state.

One important difference between Locke and Rawls centers on whether adherence to a religious tradition by itself is good evidence that someone is or is not committed to respecting the terms of the social contract. For Locke it is. For Rawls it is not. The fact that citizens committed to coexisting in a liberal state have widely diverging views about 
religion, moral, political, and other values, is a compelling reason to accommodate rather than alienate — as Locke's liberalism does - those who accept fair terms for social cooperation. Greater sensitivity toward the fact of pluralism has led to new ways of thinking about the moral basis for toleration. One result of this is the realization that a commitment to the idea of all persons as free and equal requires a conception of toleration that is more inclusive.

Despite philosophical differences it is appropriate to refer to a tradition in liberal thought as the Locke-Rawls paradigm. Like any tradition, liberalism is internally pluralistic. Yet this pluralism does not mean there are no meaningful ways to highlight common ground between Locke and Rawls. For example, political philosophers in this tradition can agree that how we think about toleration and liberty of conscience should be compatible with the idea of persons as free and equal. By contrast, utility is the basis for toleration according to Mill.

Mill characterizes liberty of conscience in a way that encompasses freedom of thought in general (Mill, 1978). Persons can express themselves on all matters unless when doing so they cause harm or pose an immanent risk of harm to other persons. Liberty of conscience is part of a more general defense of liberty that includes religious, cultural, political, and artistic freedoms. The moral basis for this view is utility: protecting the liberty of the individual serves both her own and society's interests in maximizing happiness. Moreover, like his predecessor Bentham, Mill's conception of political morality is secular. Utility, according to Mill, is not in opposition to religion, nor does it depend upon a religious morality. The case for liberal toleration is further bolstered by a recognition of the 'progressive' potential in human nature, which for Mill 
consists of an open-ended potential for moral, political, and cultural improvement (Rawls, 2007: 301-03). Toleration is important in part because it serves this permanent interest of both the individual and the human community.

Liberty and other liberal values form a core part of what Mill termed 'the principles of the modern world'. These principles include liberty, marriage equality, equal treatment under law, and freedom of occupation (Mill, 2007; Rawls, 2007: 297). The toleration required by the liberty principle is understood by Mill to be part of a set of principles that work to advance the interests of all persons in an open society.

A central component of Mill's approach to toleration and liberty of conscience is a strong anti-paternalism. Neither government nor citizens are permitted to use coercion to stop persons from exercising their liberty of conscience on grounds that such restrictions are in the interest of those whose freedom is curtailed. For example, in his interesting discussion of Mormon polygamy Mill announces his own objections, targeting in particular the patriarchy within Mormon marriage practices (Mill, 1978). Yet Mill defends a classical liberal standpoint by distinguishing coercive intervention from the free expressing of attitudes about the practices that are tolerated. Citizens are free to state their positions on nearly any topic. When they express opposition to a religious practice on grounds that it is patriarchal, they do not violate the requirement to tolerate something they object to. Mill does not conflate toleration with endorsement. Citizens are free to try to persuade, cajole, and argue with their fellow citizens about how they choose to exercise their liberty. By contrast, when the state prohibits freely constituted marriage practices that a majority finds repulsive, and when the harm principle does not authorize 
intervention, liberty is replaced by tyranny, whether of the majority or of some other power that lacks a moral justification for its coercive intervention.

That liberty is not a license to dominate others is central to the harm principle. Liberty imposes a strong duty of non-interference that is defeasible only when persons harm or pose a significant risk of harm to others. A practice that results in nonconsensual domination should not be tolerated. Yet when citizens claim they wish to freely exercise their liberty in ways that many find objectionable, the burden for intervening to prohibit should be on those who want to intervene, and not those who want to exercise their liberty.

Mill's view differs from the Locke-Rawls paradigm in three important respects. The first is that utility rather than a moral conception of the person is the moral basis for liberty of conscience. Instead of invoking the intrinsic worth of persons Mill, like other utilitarians, claims that the primary moral value is happiness. Liberty of conscience and other liberal principles are grounded in utility. The second is that harm to others rather than denying an inviolable moral status of the person is the criterion for deciding when to restrict liberty of conscience. Harm to others is a common variable in both traditions of liberal thought, yet the conception of harm that justifies coercive intervention differs across the two traditions. Mill emphasizes harm to the welfare of other persons, whereas the Locke-Rawls tradition emphasizes the intrinsic moral worth of persons, which is taken to be the basis for fundamental rights. Rights are important to a Millian conception of toleration, yet rights are grounded in utility and limited by the harm principle. Rights occupy a different space in the moral architecture of the two traditions of liberalism. A third important difference concerns the moral basis for the political authority that 
enforces liberal values, including toleration and liberty of conscience. Mill follows Hume (2015) and others in rejecting social contract theory. According to the noncontractarian liberal, political authority is justified when exercised according to the right political values, such as liberty and equality. The social contract tradition of which Locke and Rawls are paradigm figures claims that some form of consent—real, tacit, or hypothetical - is a condition for political authority, including the authority to enforce a right to liberty of conscience. The contractarian and non-contractarian liberal traditions thus disagree about the basis for the political authority to enforce a commitment to toleration and liberty of conscience. Non-contractarian liberals agree that consent plays an important role in a liberal society, for example, in commerce and in decisions about whether to join a religious community. Yet the idea of a social contract as the basis for political authority is rejected.

The harm principle can be invoked in ways that do not depend on Mill's utilitarian liberalism. For example, some contemporary positions appeal to a rights-based rather than utility-based conception of liberty. Others such as Feinberg (1984: 18) defend a conception of harm that can justify coercive intervention without taking a stand on whether the moral basis for this conception is utility, rights-based, or contractarian. Cohen (2014) develops a theory of toleration in the tradition of Feinberg which extends the anti-paternalism implied by the harm principle to a range of contemporary debates. This more recent work has shown that one can creatively combine ideas from different conceptions of the liberal political values. Though the focus here has been on Mill's version, the harm principle can be adapted to different conceptions of liberal political morality. 
On matters of law and policy there is a lot of common ground between liberals who affirm different conceptions of liberal values. Liberal political philosophers typically favor a civil libertarian conception liberty of conscience. Mormons, Muslims, Zoroastrians, atheists and others, should be tolerated with respect to their various faiths, convictions, and traditions. They also typically agree that that government should not promote sectarian religious viewpoints. On matters of conscience, most liberals will concur that toleration requires a religiously non-sectarian state, the accommodation of non-traditional and minority religious viewpoints, as well as liberty of conscience for non-religious values.

The features to liberal thought that hold across traditions of liberalism help to explain the relative agreement on a number of policies designed to protect liberty of conscience. For example, it is unlikely that a liberal political philosopher will endorse forcing religious citizens to make public pledges to secular symbols if such citizens object on religious grounds. Liberal political philosophers will also oppose obstructionist efforts on the part of citizens or government to make it harder for religious minorities to build a place of worship or to engage in religious practices. Tyranny of the majority was a special concern of Mill in part because he recognized that democratic states are often dominated by majorities who are able to use their power in ways advantageous to themselves and harmful to minorities. The treatment of Mormons and Catholics in the $19^{\text {th }}$ C America (Smith, 2015), and Muslims today in both Europe and the U.S., confirms the salience Mill's concern. Moreover, an immigration policy that makes it harder for members of one religious group to migrate for travel, study, or residency is on its face intolerant in ways liberal political philosophers oppose. 
Those in the Rawlsian tradition hold that to protect against the tyranny of the majority formal recognition of basic rights is not sufficient. The fair value of liberty will not be realized if relations between citizens are marked by significant status and material inequalities. Likewise, toleration does not require permitting people to opt out of policies that serve a compelling state interest, such as immunizing a population from polio. From the standpoint of liberal toleration polio and polygamy differ. Polio is a threat to that is hard to protect against without a vaccine, and unvaccinated persons pose a risk to those too young for a vaccine or those whose vaccines are defective. There is no analogy here with polygamy because, 'protecting oneself from the harm of polygamy' is a matter of choice in a way the protecting oneself from communicable diseases that others may carry is not. To be sure, some idealizations are being made here about marriage. In a gender inegalitarian society, other factors are on the scale. A feminist liberal perspective can offer guidance on whether the conditions for consent in marriage are reasonably satisfied or not (Brake, 2012). Likewise, both the harm principle and the idea of persons as free an equal will weigh the interests of third parties, including children, whether the issue is public health, marriage, or any number of other examples that generate conflicts between what people claim they have a liberty to do and the limits of toleration.

The discussion here is not meant to be a contribution to Locke, Mill, or Rawls scholarship, but is instead a highlighting of central features to liberal conceptions of toleration and liberty of conscience. We can better understand contemporary debates by appreciating how they draw from ancestral versions of the liberal values that animate contemporary debates. In that respect historical trends in liberalism are important to how toleration and liberty of conscience are examined here. The sketch just provided is 
framed with an eye toward contemporary debates, which is the focus of the rest of the chapter.

\section{Toleration, Neutrality, and Religious Equality}

Part I briefly considered representative positions on toleration and liberty of conscience from the history of liberal thought. Even granting that some ideas are settled, such as persons hold moral claims against many forms of coercion that restrict their liberty, there are a number of controversies about how best to realize toleration and liberty of conscience. Some controversies concern how liberal states try to promote toleration and protect liberty of conscience through law. For example, by what criterion can we judge someone's complaint that her liberty of conscience has not been respected? When does accommodating one person or group create an unfair burden for another person or group? Does the American practice of giving preferential treatment to exercises in religious over non-religious conscience violate equal treatment? One way to grapple with these questions is by proposing neutrality as a criterion for evaluating state policy. A second is to defend religious equality as the best way to protect citizens from religious intolerance.

This section considers contemporary views on neutrality and religious equality that emphasize how different principles can work together in the service of toleration. Neutrality and religious equality are not mutually exclusive, although at times they will be considered separately in what follows. One can argue for example that state neutrality is a means to the realization of religious equality. Just as political philosophers argue in different ways for priority relations between principles (e.g. fair equality of opportunity over the difference principle) this architecture is also possible for principles within a conception of toleration. 
To motivate thinking about neutrality and equality we can consider an example. Suppose we claim that an immigration policy that severely restricts immigration from a number of Muslim majority states is objectionable. Perhaps we claim such a policy too closely resembles the discredited Chinese exclusion policies in late $19^{\text {th }}$ and early $20^{\text {th }} \mathrm{C}$ America (Mahoney, 2019). One way to express this judgment is to claim that the policy is intolerant because it fails to treat prospective Muslim immigrants in the same way it treats prospective Christian immigrants. On its face such a policy looks like an instance of official religious inequality. By contrast, one might defend the policy by showing the intent behind the policy has nothing to do with religious identity, but instead some other factor, such as national security. If there are unusually high numbers of bogus passports that are difficult to detect, a lawmaker might invoke this as a reason for greater scrutiny for visa applicants from some countries. On this view, if the reasons for the policy are what matter, and if these reasons are neutral towards religious groups, the disparate impact would not imply the policy is illegitimate. One issue here is deciding which is more salient when assessing a claim to neutrality: intent or impact. Which should be emphasized might depend on other factors, such as whether the state in question has a history of objectionably exclusionary policies that disfavor members of a religious group affected by the policy. In such cases, the suspicion level that a state is attempting to defend its policy in bad faith is elevated. A conception of toleration should give us resources to expose bad faith efforts to invoke what is presented as a fair principle, but which is really an effort at rationalization in order to confer 'legitimacy' on an objectionable policy. Recent accounts of neutrality and religious equality are offered in part to address practical questions like these. 
In the contemporary context Alan Patten $(2014 ; 2017)$ defends one of the most compelling conceptions of neutrality. His view bases the idea of neutrality on fair equality of opportunity for self-determination (FOSD). This formulation has the virtue of making clear that neutrality is not a foundational principle. Rather, neutrality serves its purpose by helping us determine whether state policy treats each of its citizens as they deserve to be treated. A recent defense of religious equality is defended by Martha Nussbaum (2008). On her view religious toleration is required in part because the capacity for liberty of conscience deserves appraisal respect (Leiter, 2012; Maclure, 2018). On this view, there are good moral reasons to treat religious conscience in a way that affirms its intrinsic value. Nussbaum uses examples from American political and legal history to illustrate success and failure stories. She favors the religious exemption model sometimes affirmed in First Amendment jurisprudence according to which religious exemption claims should sometimes be accommodated.

Neutrality is not foundational to a liberal conception of morality, because it depends upon a more basic set of principles (Patten, 2014). Like toleration, which depends on a concept of the person, utility or some other basic value, neutrality is a “normatively dependent concept" (Forst, 2017: 1). For example, on Patten's view fair equality of opportunity is prior to neutrality. Thinking about neutrality in relation to other political values helps us see how a neutrality standard can serve as a basis for evaluating law and policy. Consider a policy that prohibits slaughtering animals within city limits. Posed abstractly, 'is the policy legitimate?' might seem straightforward if we are envisioning the policy as motivated to stop animal cruelty. Rationales for the policy could include: public health, limiting cruelty to animals, or regulating the production of 
meat products. Each on its own looks like a permissible reason for a policy. Yet suppose there is a religious minority committed to the ritual slaughter of chickens. If those whose religious practices are curtailed by the policy claim that their right to liberty of conscience is unfairly restricted, how should we reply? A neutrality test might help us decide how best to answer. For example, if there is reason to believe the lawmakers' motives included a bias against the religious minority whose practices are curtailed by the law, we see the policy in a different light. From this perspective it looks like the state is formulating public policy in a manner that hides the policy's actual rationale. Public health might remain a compelling public policy reason for the law. Yet a neutrality test would highlight the objectionable motives of the lawmakers, which might suffice to invalidate the policy.

If we opt for a neutrality approach to evaluating law and policy, we need to be clear about which aspects of public policy are subject to review by a neutrality test. Does neutrality apply to the motives behind state policy? Or are the effects of a policy more salient? We can imagine a public health policy, such as one prohibiting the slaughter of animals within city limits, adopted by lawmakers in good faith who harbor no bias against a religious group. From the standpoint of toleration this would matter. Yet so would the impact of the policy on religious citizens. If impact is more salient than purpose, neutrality will protect a wider range of expressions of religious freedom. To illustrate, let's consider another example.

Consider a federal education law that requires parents to ensure their children receive an adequate formal education, either in a school or at home. Whatever the adequacy standard (e.g. high school diploma or equivalency, minimum competency 
across a range of subjects) suppose the law is adopted on grounds that each citizen is entitled to a fair opportunity to pursue forms of employment that requires skilled labor, etc. Such a policy adopted on the basis of an educational adequacy approach to state education policy can meet a neutrality of intent test. Yet its effects will not be neutral across religious communities if one or more religious community believes that such a policy conflicts with religious obligation. Neutrality of effect is a possible test for the fairness of such a policy. Yet since neutrality is not a fundamental political value, there might be other considerations in a case like this, such as fair equality of opportunity for children. If the education policy was motivated by and satisfies a fair equality of opportunity standard, and if this is judged to be a legitimate policy aim on grounds that children have rights to opportunities that would be undermined were the exemption granted, the religious objection to the policy is much weaker. By contrast, suppose lawmakers developed an educational adequacy standard during a period of great social hostility towards a religious group who would have to modify its religious practices to comply with the adequacy standard. Would that impact the legitimacy of the policy?

Patten defends three ideas that are helpful as a guide to these issues. First, neutrality "is a constraint that has genuine weight and reflects significant liberal values, but it sometimes gives way to other considerations" (Patten, 2014: 106). Second, Patten proposes a neutral treatment conception of neutrality. On this view, "The state violates this requirement when, relative to an appropriate baseline, its policies are more accommodating of some considerations of the good than they are of others" (Patten, 2014: 113). Third, persons "should be given the most extensive opportunity to pursue and 
fulfil her ends that is justifiable given the reasonable claims of others" or FOSD (Patten, 2017: 208).

When we make a judgment about a state-religion policy we should consider both the reasons for it and its effects. To do this we need some standard. FOSD is one proposal. A reason counts as neutral when it is consistent with FOSD. This does not mean that all such reasons are sufficient to vindicate the policy; there are other political values that weigh in. An education policy that serves a legitimate aim such as fair equality of opportunity might conflict with another legitimate aim such as protecting the liberty of parents to make decisions about their children's education on the basis of religious convictions. Judgments about cases like this will reflect views about which values weigh in and whether some such values override claims to religious freedom.

FOSD is egalitarian in the following sense. FOSD is prior to neutrality. FOSD is among the considerations that a policy that satisfies neutrality must be compatible with; if a law satisfies neutrality but not FOSD, then the law could be opposed. For instance, a state policy that grants religious parents exemptions from a state education policy might pass a neutrality test, yet run afoul of FOSD. If students have a right to an adequate education, one that does not block opportunities for pursuing higher education for instance, then limiting parental discretion in this context may be justified.

FOSD likewise assigns a degree of responsibility to citizens for how they exercise their conscience. For example, the accommodation of a religious practice is not always cost free. Conscientious objector status, exemptions from health care policies, exemptions from motorcycle helmet laws, and tax relief alter the distribution of financial and other shared burdens. FOSD can help us navigate between those practices we should 
tolerate on grounds of liberty of conscience, and those we need not on grounds that doing so will impose an unfair burden on someone else.

A recent American Supreme Court verdict shows why these issues matter. In Masterpiece Cakeshop (2018) the Court ruled in favor of a business owner who refused to produce a wedding cake for a same-sex couple. At the state level the business owner was found to be in violation of the state of Colorado's anti-discrimination policy. However, this initial verdict was judged by many to be problematic. Much of the political opposition to the Colorado verdict reflected both anti-gay bias and confusion about the salience of liberty of conscience in the context of for-profit commercial activity. Yet a legitimate concern is that agents of the state whose role is to enforce antidiscrimination policy had expressed religious bias about a business owner who declined to make a wedding cake for a same-sex couple. What is the right way to handle a case in which representatives of the state express intolerant attitudes towards the religious convictions of its citizens in the course of enforcing an otherwise legitimate state policy? One option is to rule in favor of the business owner without striking down the antidiscrimination policy, which is how the Court ruled. Yet the Court could have both made clear that expressions of religious bias by agents are inappropriate, while at the same time upholding an anti-discrimination policy designed to reduce harms to an historically oppressed group (Macedo, 2019). Claims for either position will not be resolved by appealing to the idea of toleration alone. Patten's framework pays off because it offers a way to think through conflicts with a principle, FOSD, that specifies how to give a number considerations, including equality and liberty of conscience, their due. 
Martha Nussbaum argues for a conception toleration and liberty of conscience based on the idea of religious equality. On her view, the tradition of religious equality in the American context serves as a model, albeit with the important qualification that we need to acknowledge the many failures to honor religious equality in practice when religious bigotry undermines the realization of religious equality. Moreover, Nussbaum does not oppose developing this model in a way that is more inclusive, for example, by expanding the idea of conscience to include non-religious convictions. A secular citizen whose moral convictions put her at odds with a legitimate state policy should not be dismissed simply because the convictions are not religious. Religious exemptions have a special place in Nussbaum's view, however, in part because past instances of religious intolerance should inform our commitment to religious toleration, in particular, intolerance against religious minorities such as Mormons, Catholics, and Jews.

The central ideas in Nussbaum's position can be summarized as follows:

1. Conscience is a source of purpose and meaningful conceptions of how to live.

2. A free conscience permits persons to explore questions about the meaning of life unhindered by others and the state.

3. Conscience has intrinsic value, in the same way that the capacity for autonomy has intrinsic value.

4. Although not all values arrived at from liberty of conscience are religious values - e.g. a secular moral argument for pacifism can ground a legitimate exemption claim against mandatory service in the military - many authentic deliverances of conscience are religious, and religious convictions are often the target of state sponsored oppression and intolerance by citizens. Therefore, religious values hold a special place among the values people affirm and religious conscience serves as a model for the kinds of value commitments that merit special protection from government (Nussbaum, 2008: 22-6) 
Religious equality means that government should be neutral between religions, and refrain from taking sides, for example between Christianity and Islam. This puts a strong burden on government to refrain from adopting policies that impact persons because of their religious identity.

A religious equality approach such as Nussbaum's offers a strong counterpoint to a recent Supreme Court decision that effectively blocks immigration from a number of Muslim majority countries. In Trump v Hawaii (2018) the U.S. Supreme Court argued that despite President Trump's numerous anti-Muslim comments, both before and during his presidency, the government had made an effective case for the policy on national security grounds. The Court further claimed that both legal precedent and the Constitution favor great deference to the executive branch regarding its judgments about national security. It is worth noting that although a claim about religious equality might not override a national security argument in every instance, in this one a commitment to religious equality offers a compelling counterpoint. In actuality the claim in favor of the restrictive immigration policy is an effort by government to rationalize religious bigotry with a pretense of claiming national security is the primary concern (Mahoney, 2019). One clear piece of evidence in favor of this assessment is the gratuitous last minute addition of two non-Muslim majority states - Venezuela and N. Korea - to the visa ban.

The idea of religious equality is built around this abovementioned conception of conscience that is central to Nussbaum's project. In practice this means that a legitimate state can refrain from endorsing a sectarian religious viewpoint while at the same time affirming the value of religion as such. Sometimes American First Amendment 
jurisprudence has followed this model, and this is the conception of religious equality that Nussbaum seeks to defend as on that is suitable for a liberal theory of toleration.

Like Patten, Nussbaum is clear about priority relations among the considerations in play when we think about toleration and liberty of conscience. Religious equality is prior to neutrality. Stated quickly the order of ideas here runs from liberty of conscience, to religious equality, and then to neutrality. Though the content of her view differs from Patten's view which adapts a way of thinking about equality from theories of distributive justice, the architecture in both views is similar in the sense that each affirms that equality is more basic than neutrality. It is a requirement of justice that government affirm a conception of religious equality. Neutrality is an instrument for realizing a more fundamental principle; it is an instrument in the sense that it helps us consider whether reasons for a law or policy are consistent with a commitment to religious equality.

Nussbaum's position has the merit of highlighting social status inequalities that often harm unpopular religious minorities. A state that affirms an ideal of religious equality, especially when its legal practice has a longstanding tradition of granting religious exemptions, can reform both its legal and political culture in ways that render its commitment to religious toleration more inclusive and more equalitarian. In the American context a clear example is the difference in social status that is conferred by various forms of religious identity. Mainline Protestant Christianity has something akin to an unofficial 'first among equals status'. Mormon, Muslim, and Native American religious identities often correlate with barriers to numerous opportunities which Episcopalian or Presbyterian citizens for example can take for granted. The legitimate fairness concerns raised by those who oppose favoritism towards religious over non- 
religious convictions that conflict with state policy should not detract from the ongoing effort to reduce the effects of religious bias.

Some liberals oppose exemptions (Barry, 2001) while others oppose preferential treatment of religious convictions. (Leiter, 2012; MaClure, 2018; Perry, 2018). Brian Barry argued that when a citizen has a strong argument against being required to comply with a law, this is a reason to rescind the law. A religious citizen who makes a compelling argument against having to comply with a law on grounds of religious freedom is thus really providing a compelling reason for the claim that the law is illegitimate. Those who oppose favoritism towards religion but not exemptions claim that whether a state accommodate a religious practice at odds with state policy, ought not to depend on whether the reasons citizens have for endorsing the practices are religious or non-religious. Nussbaum's position is much closer to the exemption paradigm that informs American law. American law does not exclude non-religious exemptions, yet it favors religious over non-religious exemption claims as a matter of legal practice.

\section{Three Challenges}

This section explores challenging questions that can be posed to liberal conceptions toleration and liberty of conscience. First, how can we formulate a conception of liberty of conscience that is not objectionably biased in favor of some kinds of values over others? Second, should liberals claim that toleration and liberty of conscience require a secular state? Third, what is best strategy for proponents of toleration and liberty of conscience to mitigate the problem of bias and exclusion? 
Liberty of Conscience: Which Values Matter? In American law there is a tradition of favoritism for religious over non-religious exemption requests. Legal precedent is not uniform, but it does lean toward preferential treatment of religious over non-religious exemption claims. Recent statutory law, such as the 1993 Religious Freedom Restoration Act (RFRA) puts a higher burden on policy which conflicts with religious convictions. If a religious citizen objects to having to comply with a policy for religious reasons RFRA says the burden is on government to show that the policy that is being contested serves a 'compelling state interest' and imposes less of a burden on the practices of the claimant than alternative policy options. This level of accommodation is not guaranteed for nonreligious claimants. Since the mid-1960's as commentators have noted (Greenawalt, 2006; Nussbaum, 2008) the trajectory in American law is towards a more inclusive conception of liberty of conscience, one that still privileges religious over non-religious convictions, but overtime to a lesser extent than in the past.

Switching perspectives from law to political morality there are a range of positions religious exemptions (Vallier and Weber, 2018). Much of the most recent work on exemptions has been devoted to showing that equality and fairness in this support a conception of toleration that is neutral between religious and non-religious values. Many who favor granting exemptions argue the state should not favor religious over nonreligious exemption requests. This model is preferable to one that grants special privileges for religious exemption claims, although it too is open to objections.

Suppose we claim that toleration is best honored if we adopt a conscience principle according to which citizens can sometimes be entitled to special legal accommodations. Watching the World Cup and conscientious objection to military 
service, for religious or secular moral reasons, might seem to most persons to reflect nonmoral and moral values, respectively. Yet as Simon Cabulea May (2017) shows there are a range of kinds of commitments that include non-moral value commitments that are central to persons' conceptions of the good. Citizens can pursue scientific, artistic, intellectual, athletic, and other activities with an earnest conviction that a life with meaning requires unhindered opportunity to pursue such activities. Why should their efforts to pursue values in the service of a meaningful life be treated as less weighty simply because such values are not picked out by a conscience principle that gives priority to moral over non-moral values? Lacking a clear basis for sorting values into those which are important and those which are trivial, we will be left with a dilemma: either we unfairly exclude some exemption requests that should be taken seriously, or we face a slippery slope that will be too inclusive. Moreover, authorizing the state to adopt a principle according to which some value commitments are trivial while others are profound comes at the risk of permitting government to adopt a sectarian position on matters about which reasonable citizens can disagree.

There is reason for skepticism about a conscience principle that is neutral between religious and moral convictions, because it leaves important questions unsettled. If we attempt to address this worry by claiming the conscience principle should treat equally any meaning-conferring conviction, regardless of the kind of value, the gain in inclusivity will be accompanied by new worries. The legal impact of adopting an inclusive conscience principle would require asking whether a distinction between significant and trivial values can be fairly applied, and if so, how such a standard might be developed. 
We can partly address worries about how to specify which values the conscience principle makes eligible as the basis for exemptions by adopting Patten's idea of equal treatment and fair opportunity for self-determination. Patten's FOSD is neutral between kinds of values. It specifies limits to accommodation in terms of costs that must be shouldered by others. Expecting citizens to bear some responsibility for their pursuits, religious or otherwise, is one way to mitigate what might reasonably be claimed to be an unfairness. However, can FOSD provide guidance on how to distinguish an exemption request that would enable watching the World $\mathrm{Cup}$ from an exemption request that would enable someone to ride a motorcycle without a helmet because a helmet conflicts with a religious obligation to wear a turban? If one worker has to forgo a day off so that her coworker can watch the World Cup, is she unreasonably burdened? If a Sikh is permitted to ride a motorcycle without a helmet is his risk of incurring higher medical expenses an unfair burden placed on others? The kind of value invoked could be ignored with a conception of toleration instead being guided by the idea that each is entitled to a fair pursuit of any kind of value. Many will be unsatisfied with this approach insofar as it accommodates accommodation requests for what many will regard as trivial pursuits. Whether the liberal state should declare something like 'one person's mere preference is another's life-defining project' is an interesting and open question.

We can consider multiple policy options. For example, labor policies that specify the legitimate reasons for time-off from work that must be in place to accommodate the conscience principle. Or raising insurance premiums for those who forgo safety measures for reasons of conscience. Nevertheless, once it is claimed that toleration favors exemptions, questions about fairness and inclusivity are inevitable. This does not 
mean we should abandon the exemption approach to liberty of conscience altogether. Doing so on grounds that there will be intractable disagreement over which kinds of exemption claims have merit arguably represents reflects a sour-grapes approach to the political reality of hard cases. Yet the hard questions concerning whether all, some-and if so which and why—values can support reasonable exemption claims remain.

Does Toleration Require a Secular State? In his recent book, Islam and the Secular State, an-Na'im claims, "In order to be a Muslim by conviction and free choice...I need a secular state" (2008:1). An-Na'im defends a Lockean argument, albeit a version that is more inclusive than Locke's own position. The main principles in an-Na'im's view include first, the thesis that authentic religious conviction is incompatible with state enforcement of religious doctrine. Second, religious authority does not have jurisdictional authority over the civil affairs that states exist to project. Third, persons can disagree about religion yet coexist as equal citizens. Fourth, those Muslims who choose to abide by principles of Sharia can do so voluntarily. Yet no one has the right to compel others to comply with religious obligations. Though most liberal political philosophers do not engage questions about toleration and liberty of conscience in Muslim majority contexts (exceptions include Hashemi, 2009; March, 2009; Stepan, 2014), an-Na'im's position represents a familiar liberal position on toleration and liberty of conscience adapted to Muslim majority societies.

Is a state that does not exercise its authority on the basis of secular values necessarily intolerant? To address this, it is important to bear some distinctions in mind. One is the difference between a just and a legitimate state. If we interpret an-Na'im's 
claim to mean that a fully just state will be a secular state, his position is plausible from the standpoint of a liberal conception of toleration. A just state is fully compliant with liberal political morality. Real states fall short of this standard. If any states have the moral authority to coerce, they must be authorized to do so despite this fact. This is one reason why contemporary liberal philosophers distinguish justice from political legitimacy (May 2009; Rawls, 2005). A state is legitimate when it exercises is power on the basis of principles that reasonable persons - or some other proposed baseline that is lower than what an ideally just state will be based upon—can accept. For example, a legitimate state is committed to restricting religious liberty only when doing so is viewed as necessary to protect the status of citizens as free and equal, or on the basis of the harm principle. It will not seek to oppress religious minorities. Yet a state with these commitments may fall short—up to a point which will be left vague here—without forfeiting its political authority. There are many controversies about legitimacy and political authority (Huemer, 2012) yet many accept that legitimacy is a lower standard than justice.

From the Rawlsian standpoint an-Na'im's claim about religious toleration and the secular state is appropriate when we are thinking about the conditions for a just state. Yet as Alfred Stepan (2001) and Simon Cabulea May (2009) have shown, Stepan from a social science perspective, May from a philosophical perspective, there are multiple variations on the configuration of religious and political authority within legitimate states. When political legitimacy is the baseline, the secular requirement is less stringent. A religious democracy, understood as a state that protects religious freedom yet adopts some policies that reflect a majority religious viewpoint, according to this view, can 
qualify as legitimate. Alternatively put, such a state need not be liable to revolution simply because it is a religious democracy. Details will matter here, yet some actual transitional states and May's hypothetical example of religious democracy are compelling counterexamples to the claim that secularism is a condition for political legitimacy.

A second important consideration concerns what is meant by a secular state. AnNa'im's view is that a tolerant secular state is one that upholds the principle of liberty of conscience. In his words:

The separation of Islam and the state is necessary for Muslims to uphold their genuine beliefs and to live accordingly...Historically, religious leaders were either enticed to cooperate with the political agenda of rulers or coerced to do so to avoid facing harsh consequences, as illustrated by the inquisition....I am calling for the separation of Islam from the state, which means that those who control the state cannot use its coercive powers to enforce their own beliefs. (anNa'im, 2008: 56).

A familiar non-technical idea of a theocracy, or state whose purported authority is rooted in a conception of religious authority is incompatible with this idea of a secular state. Yet we need a conception of political authority that is more fine-grained than one that distinguishes a just state from a theocracy. If we accept a distinction between just and legitimate state as noted presented above, then an-Na'im's argument can be charitably construed as supporting the conclusion that that a fully just state will be a secular state.

\section{Bias and Exclusion in Conceptions of Toleration and Liberty of Conscience. A third}

challenge concerns objectionable limits to liberty of conscience that are supported by persons or states that claim to be committed to toleration. Liberal conceptions of toleration need to consider how biases or insensitivities to unfairness are often unacknowledged. There are both theoretical and practical dimensions to this problem. As 
a matter of theory, the following is a useful starting point for thinking toleration and liberty of conscience with this concern in mind:

Sometimes one hears reference made to the so called Enlightenment project of finding a philosophical secular doctrine, one founded on reason and yet comprehensive.... Whether there is or ever was such and Enlightenment project...political liberalism... and justice as fairness as a form thereof has no such ambitions. As I have said, political liberalism takes for granted not simply pluralism but the fact of reasonable pluralism; and beyond this it supposes that of the main existing reasonable comprehensive doctrines, some are religious. (Rawls, 2005: xvii)

According to the conception of political morality the later Rawls endorsed, toleration applies, up to a point, to political philosophy itself (Rawls, 2005). This means that those committed to the idea of persons as free and equal should accept that commitments to the values a legitimate state will rest upon can be affirmed for a variety of reasons from a variety of perspectives. Pluralism applies to political philosophy's account of what counts as a legitimate state. More recent work has taken this idea further by exploring, for example, the relevance of political liberalism in Islam, as well as to non-Western contexts (Kim, 2014) that have long traditions of construing political morality in collectivistic rather than individualistic terms.

Practical challenges to efforts to avoid bias in conceptions of toleration are equally important. Liberal political philosophers are always revising, often too slowly, their understanding of how to reconfigure the limits of toleration in order to reduce unfairness, biases that led to unjust exclusion, and to accommodate new moral insights that reveal unnoticed insensitivities in prevailing accounts. The effort to remedy mistakes rooted in prejudice and failures to acknowledge groups and individuals with interests that have a reasonable claim to be accommodated and affirmed as equal should be a central 
focus of how we understood toleration. Locke's failures with respect to atheists and Catholics may have been largely remedied in subsequent liberal theory. Yet it is the failures to address ways that contemporary understandings of toleration and liberty of conscience are compromised by unnoticed unfairness that should occupy us most when looking at the present, and towards the future. Neutrality tests, Patten's FOSD, Nussbaum's religious equality approach, and other conceptions of toleration can be evaluated in light of how well they fare in light of how other conceptions of toleration have failed. Liberal Muslims like an-Na'im make a valuable contribution by encouraging us to think about toleration from the standpoint of religious yet non-Christian citizens.

Constraints on moral imagination from outright prejudice to subtle sources of bias that persist in spite of good faith efforts to overcome them provide compelling reasons to insist that whichever conception of toleration we adopt it we should do so with the full recognition that the political project of realizing toleration is never finished. Given traditions of bias in law and political culture, liberty of conscience, especially for those whose values and religious practices fall outside what is imagined to be 'paradigmatic conceptions of religiosity' or 'meaningful pursuits' should framed in a way that puts this concern at the center.

\section{Future Directions}

There are many ways ideas about toleration and liberty of conscience can be developed beyond what has been considered here. This concluding section will briefly state two examples. One is to expand contexts to include they many perspectives on politics and toleration that fall outside typical discussions within liberal political philosophy. For example, in addition to considering toleration and liberty of conscience in different 
religious contexts as an-Na'im has proposed, recent work in comparative philosophy promises to make an important contribution to how liberal political philosophers think about toleration and liberty of conscience. Other contexts include those where prevailing conceptions of political morality are collectivistic rather than individualistic. Toleration and liberty of conscience as considered in this chapter fits squarely within a tradition of political morality based on the idea of value individualism: the idea that the individual person has rights or interests the merit special protections in the form of moral principles and law. Yet in the liberal tradition value individualism reflects the impact of Protestant Christianity, among other sources. Whether liberal conceptions of political morality can or should be adapted to the many global contexts in which religious and political history differ from the European experience is a pressing issue (Buchanan 2013: 249-74; Kim, 2014).

A second way work on toleration and liberty of conscience can be advanced further is by exploring ways that identity and politics inform citizens' and governments' willingness to extend toleration to each person and group. For example, in the American context, the dominant Protestant religious identity, in addition to attitudes about race and ethnicity, informs many persons' attitudes about toleration and liberty of context (Kazi, 2019). Attitudes about Islam in the American context cannot be separated from the dominant religious identity. When 'we are a Christian nation' is endorsed in contexts where national identity is at stake, the conflation of a legal status with a religious identity signals a desire to deny equal status to those with the 'wrong kind' of religious identity. When expressed inwardly to the domestic context, this has the effect of calling into question the loyalty of religious citizens who embrace a minority identity, such as 
'Muslim-American'. When expressed outwardly, for example towards refugees, visa applicants, or international students, this attitude becomes a basis for exclusion.

Consider attempts to draw an analogy between 9/11 and the Japanese attack on Pearl Harbor. Though a bad analogy, one reason this is politically effective is that religious identity is often conflated with nationality. In the crudest form attitudes that rest on this conflation are expressed in slogans such as, 'Islam hates us' or 'we are at war with Islam'. The analogy between a Muslim community center in Manhattan and a Japanese community center in Pearl Harbor was endorsed by many, because of this conflation of religious identity with nationality (Gutterman and Murphy, 2015). Politics and reality do not meet here: Islam is not a nation; no state committed an act of war against the U.S. on 9/11; and no political authority represents the world's nearly two billion Muslim population. Yet prevailing attitudes that in part reflect America's dominant religious identity, along with an undercurrent of fear of Islam, combine to reinforce a status inequality for American Muslims. Toleration and liberty of conscience as a matter of

principle are of course opposed to this politics. Political philosophers can engage this issue is by exploring ways that identity and politics impact how people think about toleration. When 'nationality' or some other category is really a proxy for 'Muslim' or any other religious group those who defend toleration and liberty of conscience must develop a clear and effective counter narrative to the political discourses that serve objectionable efforts to exclude.

\section{References}

An-Na'im, Abullahi Ahmed (2008) Islam and the Secular State. Harvard University Press. 
Barry, Brian (2001) Culture and Equality: An Egalitarian Critique of Multiculturalism. Harvard University Press.

Brake, Elizabeth (2012) Minimizing Marriage: Marriage, Morality, and the Law. Oxford University Press.

Buchanan, Allen (2013) The Heart of Human Rights. Oxford University Press.

Cohen, Andrew Jason (2014) Toleration. Polity Press.

Feinberg, Joel (1984) Harm to Others. Oxford University Press.

Forst, Rainer (2017) "Religion, Reason, and Toleration: Bayle, Kant—and US" in Religion in Liberal Political Philosophy. Eds. C. Laborde and A Bardon. Oxford University Press: 249-261.

Greenawalt, Kent (2006) Religion and the Constitution: Vol. 1 Religious Free-Exercise. Princeton University Press.

Gutterman, David and Andrew Murphy (2015) Political Religion and Religious Politics: Navigating Identities in the United States. Routledge.

Hashemi, Nader (2009) Islam, Secularism and Liberal Democracy: Toward a Democratic Theory for Muslim Societies. Oxford University Press.

Huemer, Michael (2012) The Problem of Political Authority: An Examination of the Right to Coerce and the Duty to Obey. Palgrave.

Hume, David (2015) “Of the Social Contract.” Library of Alexandria.

Kazi, Nazia (2019) Islamophobia, Race, and Global Politics. Rowman and Littlefield.

Kim, Sungmoon (2014) Confucian Democracy in East Asia: Theory and Practice. Cambridge University Press.

Laborde, Cecile and Aurelia Bardon (2017) Religion in Liberal Political Philosophy. Oxford University Press.

Leiter, Brian (2012) Why Toleration Religion? Princeton University Press.

Locke, John (1983) A Letter Concerning Toleration. Ed. J. Tully. Hackett.

Macedo, Stephen (2019) “Liberalism Beyond Toleration: Religious Exemptions, Civility, and the Ideological Other" Philosophy and Social Criticism: 370-89.

Maclure, Jocylen (2018) “Conscience, Religion, and Exemptions: An Egalitarian View” 
in Religious Exemptions. Eds. K. Vallier and M. Weber. Oxford University Press: 9-20.

Mahoney, Jon (2019) "Wedding Cakes and Muslims: Religious Freedom and Politics in Contemporary American Legal Practice.” Politoligia: 25-36.

March, Andrew (2009) Islam and Liberal Citizenship: The Search for an Overlapping Consensus. Oxford University Press.

Masterpiece Cakeshop v Colorado Civil Rights Commission (2018) No. 16-111, 584 U.S.

May, Simon Cabulea (2017) "Exemptions for Conscience" in Religion in Liberal Political Philosophy. Eds. C. Laborde and A. Bardon. Oxford University Press: 191-203.

May, Simon Cabulea (2009) "Religious Democracy and the Liberal Principle of Legitimacy," Philosophy and Public Affairs 37 No. 2: 136-170.

Mill, John Stuart (1978) On Liberty ( $8^{\text {th }}$ Ed.). Hackett.

Mill, John Stuart (2007) On the Subjection of Women. Ed. A. Ryan. Penguin Classics.

Nozick, Robert (1974) Anarchy, State, and Utopia. Harvard University Press.

Nussbaum, Martha (2008) Liberty of Conscience: A Defense of America's Tradition of Religious Equality. Basic Books.

Patten, Alan (2017) "Religious Exemptions and Fairness" in Religion in Liberal Political Philosophy. Eds. C. Laborde and A. Bardon. Oxford University Press: 204-219.

Patten, Alan (2014) Equal Recognition: The Moral Foundations of Minority Rights. Princeton University Press.

Perry, Michael (2018) "On the Constitutionality and Political Morality of Granting Conscience-Protecting Exemptions to Only to Religious Believers." Religious Exemptions. Eds. K. Vallier and M. Weber. Oxford University Press: 21-36.

Rawls, John (2007) Lectures on the History of Political Philosophy. Ed. S. Freeman. Harvard University Press.

Rawls, John (2005) Political Liberalism. Columbia University Press.

Religious Freedom Restoration Act (1993).

Smith, David T. Religious Persecution and Order in The United States. Cambridge University Press. 2015. 
Stepan, Alfred (2014) "Muslims and Toleration: Unexamined Contributions to the Multiple Secularisms of Modern Democracies" in Boundaries of Toleration Eds. A. Stepan and C. Taylor. Columbia University Press: 267-296.

Stepan, Alfred (2001) "Religion, Democracy, and the 'Twin Tolerations,"” Journal of Democracy Vol. 11 No. 4: 37-57.

Trump v Hawaii (2018) No. 17-965, 584 U.S.

Vallier, Kevin and M. Weber (2018) Religious Exemptions. Oxford University Press. 